\title{
The Impact of Tax Governance on the Governmental Corruption level in Jordan
}

\author{
Abed Al-Rahman Mohammad Baker ${ }^{1}$, Mohannad Mohammad Al-Ibainy ${ }^{2}$ \\ ${ }^{1}$ Faculty of Business, Al-Isra' University, Amman, Jordan \\ ${ }^{2}$ Faculty of Business, Ajloun National University, Ajloun, Jordan \\ Correspondence: Abed Al-Rahman Mohammad Baker, Faculty of Business, Al-Isra' University, Amman, 11622, \\ Jordan.
}

Received: December 26, 2017

Accepted: February 8, 2018

Online Published: March 12, 2018

doi:10.5539/ibr.v11n4p119

URL: https://doi.org/10.5539/ibr.v11n4p119

\begin{abstract}
The current study aimed at identifying the impact of applying two tax governance mechanisms (i.e. direct and indirect tax control) on the financial and administrative governmental corruption levels at the income and sales tax department in Jordan in 2017. The researchers developed a questionnaire to collect data. Then, they distributed the questionnaire forms to the random sample they selected. The study's sample consists of 22 tax auditors, 8 tax supervisors, and 2 heads of the auditing departments who work at several directorates affiliated with the income and sales tax department at Jordan. The sample also includes 61 external certified auditors who were accredited by the latter department $(n=93)$. The collected data was analyzed through the SPSS program and percentages and frequencies were calculated

It was concluded that the application of the two tax governance mechanisms (i.e. direct and indirect tax control) can significantly reduce the levels of financial and administrative governmental corruption at the income and sales tax department. It was also concluded that external auditors - who are part of the tax governance system play a significant role in reducing such corruption levels through enforcing indirect tax control on the income and sales tax department.

Finally, the researchers recommend holding training programs to improve the efficiency of the employees working at the control departments of taxation authorities. They also recommend using advanced accounting and tax systems to raise the efficiency of the employees working at of the control department at taxation authorities.
\end{abstract}

Keywords: corruption, tax governance

\section{Introduction}

Corruption is a global unethical conduct that has been widely spreading in all over the world in various areas. Such areas may include: the financial, administrative, economic, social, political, judicial, and moral areas (Windssor, 2004). It is considered as a serious problem because it negatively affects all countries without exception, whether they are developing or developed. It also affects all the public and private sectors and hinders their growth

However, in the business and governmental sectors, the financial and administrative corruption are considered the worst kinds of corruption due to their major negative impacts on them and the losses resulting from them. For instance, they led to experiencing successive economic crises on the local and international levels. They also led to the collapse and bankruptcy of various international companies and banks. Hence, the researchers of the present study aimed at shedding a light on these two kinds of corruption at the income and sales tax department in Jordan.

The researchers believe that it is necessary to make reforms to fight against such corruption at the latter department. Such reforms may include enacting laws, applying useful governance mechanisms and promoting awareness among people and employees about the consequences of corruption on people and national economy. However, applying useful governance mechanisms requires investigating their role in fighting against corruption at taxation departments. Thus, the researchers aimed at shedding a light on the role of two tax governance mechanisms (i.e. direct and indirect tax control) in fighting against and detecting financial and administrative governmental corruption in the income and sales tax department at Jordan 


\section{Statement of the Problem}

There are many countries that lack valuable resources which can generate high amounts of revenue. Therefore, such countries rely much on the tax revenues to pay their public expenditures. In other words, the collected tax revenues are considered highly significant in such countries. For instance, such revenues participate in making investments, supporting national economy and increasing the economic growth rates. Thus, they shall participate indirectly in providing job opportunities and fighting against poverty and unemployment.

In the light of the aforementioned, it should be noted that acts of manipulation or corruption related to taxes shall hinder the state's growth and development. Hence, the taxation departments must perform their role efficiently to prevent and detect any corruption related to taxes, especially in developing countries that lack valuable resources. That can be ensured through applying effective tax governance mechanisms. In order to identify the effectiveness of tax governance mechanisms, they must be examined. For this reason, the researchers of the present study aimed at examining the effectiveness of two tax governance mechanisms (i.e. the direct and indirect tax control) in fighting against financial and administrative governmental corruption at the income and sales tax department in Jordan

\section{The Study's Questions}

The present study aimed at answering the following questions:

Q.1) - Is there any statistically significant impact for the application of direct tax control - as being one of the tax governance mechanisms - on the levels of financial and administrative governmental corruption at the income and sales tax department in Jordan?

$\mathrm{Q}, 2)$ - Is there any statistically significant impact for the application of indirect tax control - as being one of the tax governance mechanisms - on the levels of financial and administrative governmental corruption at the income and sales tax department in Jordan?

\section{The Study's Objectives}

The present study aimed at:

1) - Identifying whether there is any statistically significant impact for the application of direct tax control - as being one of the tax governance mechanisms - on the levels of financial and administrative governmental corruption at the income and sales tax department in Jordan

2)- Identifying whether there is any statistically significant impact for the application of indirect tax control - as being one of the tax governance mechanisms - on the levels of financial and administrative governmental corruption at the income and sales tax department in Jordan

\section{The Study's Significance}

The present study is significant due to the following reasons:

- The study's results can enhance the Jordanian national economy through providing knowledge about the significance of fighting against corruption and its reasons

- The study's results participate in raising the tax revenues which represent a significant amount of the gross domestic product. That shall lead to improve the Jordanian economy, raise the economic growth rate, reduce poverty, make investments and increase job opportunities

- The study's results are useful for the ones responsible for making policies and decisions at the income and sales tax department. To be specific, these results shall help them in fighting against corruption and reducing the tax evasion rates. Thus, these results shall improve the future performance of the latter department leading stakeholders to invest more in governmental business

- The present study fills a gap in the relevant Arab literature and provides recommendations for reducing tax related corruption. It also fills a gap in the Jordanian literature due to the scarcity of the studies conducted about this issue in Jordan

- The present study provides a review for the relevant theoretical and empirical literature related to tax governance. It also sheds a light on the seriousness of the financial and administrative corruption at governmental institutions.

- The study shall serve as a useful reference for the researchers who want to conduct similar studies in the taxation departments of other countries. 


\section{The Study's Limits}

The present study was conducted in 2017 at the income and sales tax department in Jordan

\section{Definition of Terms}

Corruption: It refers to the use of public office for achieving a personal gain. In simple words, it is the employee's use for his status, rank, or official position to get a personal benefit (Myint, 2000).

Tax Governance: Abed Al-Sami' (2008) defines it as being: a group of procedures and rules applied by the tax administration to ensure the achievement of tasks properly. They are also followed to develop their processes and raise the trust of its taxpayers in it. These are also followed to achieve justice and transparency, enforce control and hold all employees accountable for their acts. That is done to achieve the goals of tax legislations and raise people's sense of trust in the tax and economic systems of the state.

\section{Financial and Administrative Corruption and Their Forms}

Windssor (2004) suggests that there are many types for corruption, such as the financial, administrative, economic, social, political, judicial, and moral corruption (Cited in Ensaf et al., 2012). However, the present study aimed to shed a light on the administrative and financial corruption.

Administrative corruption is defined as one's misuse of position for achieving any personal gains in an illegitimate manner. As for the financial corruption, it refers to the financial deviations and violations committed against the financial rules that govern the financial works and operations at governmental intuitions. Financial corruption also involves any act that violates the regulations of the financial control authorities (Sulaiman, 2005).

According to Mohammad (2007), administrative and financial corruption have various forms. For instance, they may be represented in bribery, nepotism, favoritism, the use of connections for personal gain, forgery, blackmail, and embezzlement. They may involve the slowing down of procedures of certain paper works

\section{Reasons and Consequences of the Financial and Administrative Corruption}

According to Al-Saf, (1998), the reasons behind financial and administrative corruption can include: (Cited in Ali et al., 2013)

1)- Personal reasons: They are represented in one's personality, characteristics, educational level and views about the concept of legitimacy.

2)- Social reasons: They are represented in the customs, traditions and norms that are dominant in the society, such as the spread of favoritism

3)- Administrative and organizational reasons: They are represented in the vagueness of regulations, the complexity of the administrative procedures and the use of ineffective control methods and systems

4)- Legal reasons: They are represented in the absence of laws that enforce deterrent punishments on the ones who commit acts of financial and administrative corruption

5)- Political reasons: They are represented in appointing managers based on their political views without taking their competency into consideration. Such reasons include the absence of institutions responsible for fighting against corruption and control. They also include the poor performance of the governmental institutions responsible for control.

6)- Economic reasons: They are represented in employees' low wages, incentives, and bonuses. That shall lead employees to search for any method that can increase their income even if it's illegitimate.

7)- Reasons related to governance: Having an inefficient governance shall threat organizations' growth, and make them incur more costs,. It shall make them lose competitiveness and face difficulties in finding solutions to their problems.

As for the consequences of those types of corruption, they may include: (Kardoudi and Wasaf, 2016):

1)- They shall hinder economic growth and reduce the rates of foreign and local investments. They shall also reduce the amounts of available resources which should be used for anti-poverty programs and production.

2) The levels of such corruption shall negatively affect the amount of tax revenues. That occur when the companies submit false financial statements to the tax authorities to pay less amount of taxes. That also occurs when the tax authority does not enforce taxes on certain people of high economic and political authority. That shall in turn affect the credibility of the tax authority and increase the tax gap.

3)- When the officers of the tax authority accept bribes to reduce the payable taxes and tax rates, the government 
revenues shall decrease. That shall lead to raise prices, and foreign debts and experience an interference by foreign countries in making decisions.

4)- They shall increase governmental expenditures and lead to a poor management of resources

5)- They shall increase poverty rates and result in poor distribution of income. That shall increase the gap between the rich and the poor, raise the prices of governmental services and decline the living condition

6)- They shall negatively affect the stock exchange markets and investment funds. For instance, the false financial statement shall mislead the stakeholders when making decision leading to a stock market crash, bankruptcy and economic crises

\section{Tax Governance and Its Significance}

According to Al-Janabi (2009), tax governance refers to a group of procedures that organize and govern the relationships between all the tax administration officers and taxpayers. Thus, enforcing an efficient corporate governance on the tax administration would result in disclosing its works, raising their levels of transparency, achieving objectivity and holding employees responsible for the application of the applicable laws and regulations. That shall make all the concerned parties enjoy the rights entitled to them. To add more, tax governance shall protect the state's revenues, and prevent any violation made against the law. Tax governance shall also protect the rights and interests of tax payers.

\section{The Strategic Objectives of Tax Governance}

According to Abu Omar (2010), the comprehensive application of tax governance shall achieve tax reforms that shall serve the interests of all the parties involved in the taxation process. As for Abed Al-Men'im (2008), he believes that tax governance aims at:

1)-Achieving fairness and efficiency in the tax administration and its works.

2)-Raising people's awareness about tax related matters and instilling a sense of compliance to paying taxes willingly among taxpayers.

3)-Improving the electronic processing of tax declarations and data. The researchers of the current study also believe that achieving this objective shall participate in saving time and the efforts exerted by the tax administration employees. That shall lead to achieving the desired tasks in the appropriate time.

4)-Making improvements on tax systems in a regular manner

5)- Benefitting from the technological developments in performing works at the tax administration.

6)- Developing a special incentive system for the employees of the tax administration to encourage and motivate them.

7)- Having accurate statistics about the number and data of the tax population which shall prevent tax evasion and reduce the tax related disputes and lawsuits (Abed Al-Men'im, 2008, p.49).

7)- Improving the efficiency and competency of the employees working at the tax administration

8)- Improving the performance level of the tax administration to meet the total quality standards (Andreas, 2009)

\section{Elements of the Tax Governance System}

Hanna (2005) believes that the tax governance system consists from the following elements:

1)-Tax legislations: They refer to a group of laws, regulations, and systems that aim to enforce taxes, determine their value, and collect them. These laws, regulations, and systems also aim to govern the processes carried out by the tax administration and regulate the tax administration's relationships with the people it deals with.

2)- Tax administration: It refers to all the public directorates that are responsible for applying and enforcing the income and sales tax act through the auditors and employees. They apply and enforce this act through determining the tax values, conducting tax inspections, and communicating with the other governmental departments to ensure that taxes have been paid by the tax payers and investors.

3)-Tax population: It refers to the all the natural people involved in taxation process, such as: the taxpayers, and tax lawyers, consultants, accountants, and auditors. It also refers to the legal people dealing with the tax administration, such as: the public and private joint stock companies.

The researchers of the current study believe that figure (1) presents the elements of the tax governance system and the relationships between them. Identifying such relationships shall enable officials to enact a clear and comprehensible tax act that can identify the responsibilities and duties of the tax administration. Through such an 
act, taxes shall be enforced in a fair manner on the tax population and the involved parties would enjoy all their rights. This act shall also settle any dispute that may arise between the members of the tax population and the tax administration.
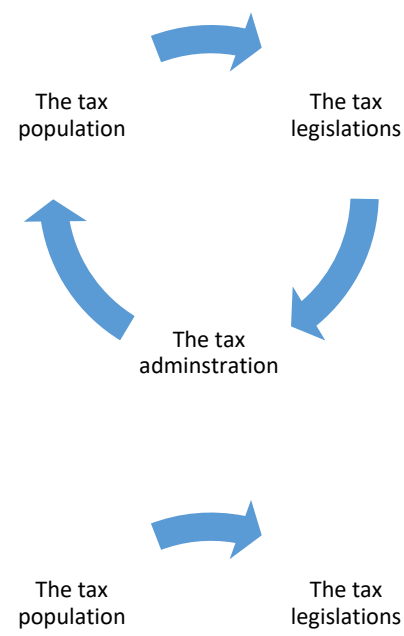

Figure 1. Elements of the tax governance system (Designed by the researchers of the current study based on the study of Hanna (2005))

\section{The Tax Governance Mechanisms}

Zanoni and Janssens (2005) suggests that direct control (i.e. bureaucratic control) refers to exercising power through traditional methods of direct control and ensuring employees' compliance to the rules set earlier. As for the indirect control, they state that it is based on the Foucauldian idea and define it as the control arises from one's sense of identity and operates through the self rather than being imposed on the self. They state it is the product of social relationships. In other words, it refers to regulating people's identity to make them indirectly controlled by the regulations of their own professional identify. They state the indirect control refers to the self-positioning of employees within a managerially inspired discourse about the organization and work which shall turn them into being more or less committed.

Governance adopts several mechanisms and the same applied to tax governance. However, the most significant tax governance mechanisms are represented in tax control, including the direct and indirect ones. As for the direct tax control, it includes performance control and organizational control. The organizational control refers to the extent of applying the law by the tax administration and how correct its enforcement is. As for the performance control, it is based on the following:

A)- Enforcing control over the extent of applying the rationalization principle in the activities and policies of the tax administration. That is done to ensure that they adopt the rationalization principle properly and correctly. That shall save the costs in the tax administration. Such control shall ensure the employees' compliance to the actual costs needed for providing the required quantity and quality of services (Seyam, 2009)

B)- Enforcing control over the tax administration's efficiency in using the available human and financial resources. In other words, efficiency should be connected with rationalization in the use of these available resources. Through applying the efficiency and rationalization principles, the tasks shall be achieved in a way that is consistent with each case. It shall also ensure that the tax administration is using the techniques required for handling each case in a way that suits it (Abu Omar, 2010)

C)- Enforcing control over the performance effectiveness that concerns the tax administration's tasks related to its goals. Such tasks include: collecting taxes, providing the state with sufficient tax revenues, making a census 
estimation for the number of the tax population, and reducing the rates of tax evasion (Eid, 2010). Thus, this effectiveness must be achieved through identifying the tax administration's main goals in accordance with each managerial level (i.e. upper management, middle management, and line management). In addition, the tax administration must keep tracking its performance effectiveness in accordance with each managerial level. Furthermore, tasks should be identified implicitly and clearly to achieve the performance effectiveness at the tax administration(Eid, 2010)

Based on the aforementioned, promoting the application of indirect control among taxpayers is considered one of the most important tax control pillars. The researchers believe that promoting the application of this control can be done through:

- Raising the accuracy and effectiveness of the internal control: This control is represented in the administrative, and accounting control enforced by companies on themselves

- Keeping the accounting records that are issued regularly in pursuant to the international accounting standards.

- Auditing the company's accounting records by external auditors.

\section{Significance of Control in fighting against Corruption}

Al-Zahawi (2008) believes that control aims at: (Cited in Ensaf et al., 2012):

1)- Protecting public funds and ensuring employees' compliance to the law and regulations. Control also aims at checking the validity of employees' financial practices

2)- Detecting any deviation, error, or violation in governmental bodies and organizations

3)- Controlling and assessing performance in accordance with the applicable law

4)- Issuing opinions about the validity of the financial statements and ensuring their compliance to the accounting standards

5)- Auditing and controlling the accounting records of governmental organizations to make sure that laws are applied properly in relation to collecting tax and spending public expenditures

6)- Making sure that public officers are not misusing their powers for achieving any personal gain

7)- Identifying the actual financial positions of organizations and the actual investment returns

Al-Bkou' and Ahmad (2012)believe that using internal control systems shall significantly reduce the financial and administrative corruption levels in service organizations. That shall promote positivity among employees and reduce the costs of investment projects

Murad and Amin (2017) believe that internal control plays a significant role in fighting against financial corruption. They believe that such control also enables the management to take useful decisions and detect the shortcomings in its works. In addition, such control enables the management to detect financial corruption acts and identify their reasons. They also believe that the organization's lack of compliance to the laws indicate that there are shortcomings in its internal control system. They also suggest that poor internal control shall raise the rates of financial deviations and violations.

\section{Empirical Literature}

Majeed (2010) aimed at identifying the impact of applying internal control on the financial corruption levels in Iraq during (2006 - 2008). He developed a questionnaire and distributed the questionnaire forms to the random sample he selected. The sample consists from 90 employees working at the internal control department of the Iraqi central bank and auditors working at external audit offices. However, 80 questionnaire forms were retrieved which are valid for statistical analysis. It was concluded that the institution's lack of commitment to the law and regulations indicate that there are shortcomings in the internal control system. In addition, it was concluded that poor internal control shall increase the probabilities of committing deviations and violations which are one of the forms of the financial and administrative corruption. He also concluded that using effective taxation and accounting systems shall significantly reduce the financial corruption in Iraqi institutions.

Al-Ebaidy and Al-Samerai (2012) aimed at exploring the reasons behind committing tax evasion acts which are one of the forms of tax corruption. Their study was conducting in Iraq through examining the records of the Iraqi ministry of finance and the general commission for taxes during the period $(1995-2010)$. They concluded the tax evasion rates in Iraq are high due to the poor control enforced on companies and individuals which lead to reducing the investment rates. 
Ali et al. (2013) aimed at identifying the impact of applying corporate governance mechanisms and rules on the strategic performance of the general commission for taxes at Iraq. The latter researchers developed a questionnaire. After that, they distributed the questionnaire forms to the sample. The sample consists from the heads of departments and officials who were working at the general commission for taxes (GCT) and academics who are specialized in accounting, auditing and management. The sample also includes professionals working in audit offices and officials working in the state financial control bureau. 93 questionnaire forms were distributed, but 86 were retrieved and all of them are considered valid for statistical analysis. They concluded that the application of the corporate governance mechanisms is highly significant due to their positive impact on the taxation system and the fulfillment of the commission's strategic performance. They also concluded that such application shall fulfill the political, social and economic goals of the state's taxation policy. They also concluded that such application shall reduce tax evasion, and tax gap rates and encourage the commission's employees to follow the regulations and rules

Zaher et al. (2014) aimed at investigating the impact of implementing corporate governance mechanisms on the financial and administrative corruption levels in the Syrian private banks in 2013. They distributed questionnaire forms the sample they selected. Their sample consists from 73 board members, financial managers and executive managers who work at Syrian banks. However, 66 questionnaire forms were retrieved. It was concluded implementing corporate governance mechanisms shall reduce the financial and administrative corruption levels in the Syrian private banks. They also concluded that there is a negative correlation between the latter levels and the application of internal control

Abu Odeh (2015) aimed at identifying the impact of corporate governance and corruption on tax revenues in Palestine during the years $(1996-2013)$. The latter researcher collected data from the reports published by the Palestinian ministry of finance World Bank and developed a model for measurement. She also conducted the simple regression analysis. She concluded that there is a significant positive correlation between tax revenues and corporate governance. It was also concluded that there is a negative correlation between corruption and tax revenues. It was also concluded that poor levels of disclosure and transparency shall increase the tax evasion rates

\section{The Study's Approach}

The present study adopts the analytical descriptive approach.

\section{The Study's Variables}

*The independent variable: The application of two tax governance mechanisms (i.e. direct and indirect tax control)

*The dependent variable: The financial and administrative governmental corruption levels at the income and sales tax department in Jordan

\section{The Data Collection Methods}

The researchers used two kinds of data which are represented in the following:

1)- Primary data: It is represented in the data collected through the questionnaire forms

2)- Secondary data: It is represented in the data collected from books, studies, articles, theses and $\mathrm{PhD}$ dissertations

\section{The Study's Instrument}

After reviewing the aforementioned empirical literature, the researchers developed a questionnaire to collect data from the sample. This questionnaire consists from two parts. The first part aims to collect demographic data about the sample, such as: their positions, academic qualifications and years of experience. As for the second part, it consists of(43) statements. 27 statements aim to provide an answer to the study's first question, whereas 16 statements aim to provide an answer for the study's second questions.

\section{Statistical Methods}

The researchers of the present study used the SPSS ${ }^{1}$ program and descriptive statistical methods to analyze the collected data. Through this program, percentages and frequencies were calculated and presented in tables. They were calculated to describe the respondents' characteristics and attitudes.

The researchers used the following criterion to classify percentages:

\footnotetext{
${ }^{1}$ Statistical Package for the Social Sciences (SPSS)
} 
1)- $100 \%-65 \%$ : High

2)- $64 \%-50 \%$ : Moderate

3)- $50 \%-0 \%$ : Low

\section{The Instrument's Validity}

The questionnaire was passed to five experts who are university professors specialized in management. They were asked to provide their opinions and make modifications. That was done to make sure that it is able to measure what it was set to measure. In the light of their comments, some changes were made.

\section{The Instrument's Reliability}

In order to measure the instrument's reliability, the researchers calculated the Cronbach's alpha coefficient. The results show that it is 0.91 which is a high value because it far exceeds 0.60 . That means that the instrument is highly reliable and provides accurate results.

\section{The Study's Population and Sample}

The study's population consists from 124 tax auditors, supervisors and heads of departments who work at the directorates affiliated with the income and sales tax department at Jordan. The population also consists from (384) external auditors accredited by the latter department. Such information was obtained from a circular issued by the income and sales tax department. As for the sample, it was selected randomly and it represents $30 \%$ of the whole population. Thus, one hundred and fifty four (154) questionnaire forms were distributed to the study's sample. However, ninety three (93) questionnaire forms were retrieved and all of them are considered valid for statistical analysis. As for the response rate, it is $83.78 \%$.

Thus, the sample consists from 22 tax auditors, 8 tax supervisors, and 2 heads of the auditing departments who work at several directorates affiliated with the income and sales tax department at Jordan. It also includes 61 external certified auditors who were accredited by the latter department $(n=93)$. Further details are presented in table (1)

\section{The Sample's Characteristics}

The respondents' characteristics were collected through the first part of the questionnaire. Such characteristics concern their positions, academic qualifications and years of experience.

\subsection{The respondents' Distribution According to Their Positions}

The respondents are classified into the following categories according to their positions: (tax auditors, tax supervisors, heads of auditing departments, and certified auditors). To be specific, the sample consists of 22 tax auditors, 8 tax supervisors, 2 heads of the auditing departments, and 61 certified external auditors. The percentage of certified auditors is the highest (i.e.68.75\%). As for the lowest percentage, it is the heads of the auditing departments (i.e. $6.25 \%$ ). Further details are presented in table (2)

\subsection{The Respondents' Distribution According to Their Academic Qualifications}

The qualifications that the respondents hold include the $(\mathrm{BA}, \mathrm{MA}$, and $\mathrm{PhD})$ degrees. It can be noticed that (78.125\%) of the tax auditors hold a BA degree. In addition, $88.52 \%$ of the external auditors hold a BA degree. It is noticed that $18.75 \%$ of the tax auditors hold an MA degree, whereas $8.2 \%$ of the external auditors hold an MA degree. It can be also noticed that $3.125 \%$ of the tax auditors hold a $\mathrm{PhD}$ degree, whereas $3.28 \%$ of the external auditors hold a $\mathrm{PhD}$ degree. It can be clear that most of the sampled external auditors and tax audits hold a BA degree because their professions require having a practical experience rather than holding postgraduate degrees. Further details are presented in table (3)

\subsection{The Respondents' Distribution According to Their Years of Experience}

The respondents are classified into five categories according to the years of experience they possess. However, it can be noticed that twenty one (34.4\%) of the external auditors possess more than twenty (20) years of experience It is also noticed that twelve (12) respondents of the tax auditors group possess an experience of 6 10 years which represents $37.5 \%$ of the tax auditors group. As for the other categories, they possess less experience. It is noticed that the numbers of tax auditors decrease with the increase of their experience after having more than 10 years of experience. It can be also noticed that the number of the external auditors increase with the increase of their years of experience. Further details are presented in table (4). 


\section{Results}

\subsection{Results Related to the Study's First Question}

Q.1) - Is there any statistically significant impact for the application of direct tax control - as being one of the tax governance mechanisms - on the levels of financial and administrative governmental corruption at the income and sales tax department in Jordan?

The percentages listed in table (5) aim at providing an answer for the study's first question

Based on statement (11), it can be concluded that $97.8 \%$ of the respondents believe that work tasks must be distributed well to reduce the levels of administrative negligence. In addition, statement (10) indicates that $95.7 \%$ believe that having a valid organizational plan for managing the tax payers' files shall reduce the operational costs of the income and sales tax department. These percentages are the highest percentages in table (5). The percentages listed in table (5) are high because they are within the range of $64.5 \%-97.8 \%$. The total percentage is $(85.5 \%)$ which is a very high value. It indicates that respondents believe that direct tax control can significantly reduce the levels of financial and administrative governmental corruptions at the income and sales tax department in Jordan.

\subsection{Results Related to the Study's Second Question}

Q.2) - Is there any statistically significant impact for the application of indirect tax control - as being one of the tax governance mechanisms - on the levels of financial and administrative governmental corruption at the income and sales tax department in Jordan?

The percentages listed in table (6) provide an answer for the study's second question

According to statement (24), $96.8 \%$ of the respondents believe that editing the facility's records by external auditors shall reduce the financial and administrative governmental corruption levels. As for statement (21), $94.6 \%$ of the respondents believe that providing the department with valid documents, and records shall reduce the financial and administrative governmental corruption levels at the latter department. Statement (23) indicates that $94.6 \%$ of the respondents believe that preparing the financial statements' in accordance with the international accounting standards shall reduce the financial and administrative governmental corruption levels at the income and sales tax department. As for the overall percentage, it is 80.9 which is a very high value. That means that respondents believe that indirect tax control can significantly reduce the levels of financial and administrative governmental corruption at the income and sales tax department

\section{Conclusion}

The researchers of the present study concluded the following:

1. Direct control - as being one of the tax governance mechanisms - can significantly reduce the levels of financial and administrative governmental corruption at the income and sales tax department

2. Indirect tax control - as being one of the tax governance mechanisms - can significantly reduce the levels of financial and administrative governmental corruption at the income and sales tax department

3. Enforcing efficient (direct and indirect) tax control - through procedures, regulations and follow ups- can significantly reduce the possibilities of committing acts of governmental corruption at the income and sales tax department

4. External auditors- who are part of the tax governance system - play a significant role in reducing the corruption level through enforcing indirect tax control at the income and sales tax department

\section{Recommendations}

In the light of the aforementioned results, the researchers of the present study recommend:

1. Holding more training programs to improve the efficiency of the employees working at the control department at taxation authorities

2. Using advanced accounting and tax systems to raise the efficiency of the employees working at of the control department at taxation authorities

3. Improving the organizational structure of the control enforced in the income and sales tax department in Jordan

4. Promoting awareness among people about tax related matters and the consequence of corruption on people and the national economy. That can be done through using modern communication channels, such as: social media channels 
5. Exerting efforts to improve the living conditions of the tax administration's employees through making changes constantly on their wages and incentives in a way that is consistent with the changing inflation rates. Doing that shall participate in reducing the corruption level in the administration.

6. Identifying the procedures that should be followed to conduct a tax inspection for the taxpayers' accounting records and financial statements through providing clear and comprehensible regulations.

7. Simplifying the registration and cancellation procedures adopted by the income and sales tax department through opening centers for providing the taxpayers with tax related services.

8. Conducting similar studies in the tax administrations of other countries. The researchers also recommend investigating the impact of other governance mechanisms on the corruption level at the income and sales tax department in Jordan

\section{References}

Abed, A., \& Mohammad, R. (2008). Governance in tax administration. The Scientific Journal of Trade and Finance, 3 .

Abed, A., \& Naser, A. A. (2008). Enforcing governing on the tax administration and the inevitability of enforcing it to have an objective tax performance (Unpublished MA thesis), Suez Canal University, Ismailia, Egypt, p. 49.

Abu Odeh, M. (2015). The Effect of governance and corruption on tax revenues econometrics case study on Palestine (1996-2013) (Published MA thesis), The Islamic University of Gaza, Gaza Palestine

Abu, O., \& Abed, A. M. F. (2010). A proposed framework for applying governance in the tax administration department and its effects upon the efficiency and effectiveness of its employees' performance (Unpublished MA thesis), Faculty of business, Banha Unversity, Egypt, p. 19.

Al-Bkou', F., \& Ahmad, M. (2012). Activating the internal control systems in the aim of fighting against the phenomenon of financial and administration corruption in service organizations: An analytical theoretical study. The Journal of Economics and Administration, 92, 167-181. Retrieved from https://www.iasj.net/iasj?func=fulltext\&aId=85410

Al-Ebaidy, Z., \& Al-Samerai, Y. (2012) Analysis of the phenomenon of tax evasion in and the means of treatment in the tax System in Iraq. The Journal of Al-Anbar University for Economic and Managerial Sciences, 4(9), 120-146. Retrieved from https://www.iasj.net/iasj?func=fulltext\&aId=69041

Ali, M., Hussain, A., \&Ya'coub, F. (2013). The role of governance in improving the strategic performance of tax administration. Accounting and Financial Studies Journal, 8(22), 101-126. Retrieved from https://www.iasj.net/iasj?func=fulltext\&aId=90317

Al-Janabi, R. M. (2009). The impact of governance on the market price of equity capital in banking companies (Unpublished MA thesis), Faculty of management and economics, Baghdad University, Baghdad, Iraq, p. 140.

Al-Saf, M. (1998), Code of ethics of the public position and the administrative factors leading to violate it: Applied in the Kingdom of Saudi Arabia. The General Management Journal, 82, 457.

Al-Zahawi, S. (2008). The control enforced on the implementation of the general budget in the Iraqi law, The media department at the Iraqi Parliament, First edition, Baghdad.

Andreas, G. K. (2009). Governance to improve tax in developing emerging and transitional economics, guide to building tax corporate governance in the 21 century, center for international private enter price, Washington.

Eid, M. Z. (2010). The internal mechanisms of corporate governance. The Administrative Research Journal, 1.

Ensaf, R., Rafe'a, A., \& Adnan, A. (2012). The effectiveness of the financial controlling system and its effect on the financial corruption in Iraq- applied study on Mosul university. The Journal of Al-Anbar University for Economic and Managerial Sciences, 4(8), 317-346. Retrieved from https://www.iasj.net/iasj?func=fulltext\&aId=60082

Hanna, N. F. (2005). An approach towards applying governance in the tax administration, Paper presented at the Fifth Annual Scientific Conference on Corporate Governance and its Accounting, Economic and Administrative Dimensions, Faculty of business, Alexandria University, 8 - 10 September.

Joulfaian, D. (2009). Bribes and business tax evasion. Retrieved from http://ssrn.com/abstract=904689

Kardoudi, S., \& Wasaf, A. (2016). Prevention of financial and administrative corruption from an Islamic 
Perspective: The problem of the illegitimate financial gain of public official. The Algerian Journal for Globalism and Economic Policies, 7, 221-246.

Madkour, F. (2003), Human resources management, The faculty of business, Cairo University, Egypt, p. 243f

Majeed, A. (2010). Internal control and its role in fighting against financial corruption: An empirical study in control authorities, AL-Mansour Journal, 14(Special Issue/Part One). Retrieved from https://www.iasj.net/iasj?func=fulltext\&aId=35305

Mohammad, S., \& Abed, A. (2007). Financial and administrative corruption: their manifestations and methods for addressing them: A case study applied in the committee responsible for calculating the political dismissal period for the ones covered by the decision of assessing the cost of damages and political dismissal period, Iraq. Integrity Journal, 3.

Murad, K., \& Amin, B. (2017). The role and importance of the internal control system in reducing the phenomenon of financial corruption Case study of Algeria. The Journal of North Africa Economics, 17, 53-66.

Myint, U. (2000). Corruption: Causes, consequences, and cures. Asia-Pacific Development Journal, 7(2), 33-58.

Seyam, A. Z. (2009). The role of banking governance in enhancing the efficiency of the Jordanian commercial banks, Paper presented at the Second Scientific Conference held by the faculty of business administration at the University of Jordan, Amman, Jordan, 14 - 15 April.

Sulaiman, M. S. (2005). Corruption: reality, motives, and negative consequences. Journal of Police based Way of Thinking, Sharjah, Sharjah Police Research Center, 54, 148

Windssor, (2004). Theory of limits on corruption, N.Y.

Zaher, T., Ali, G., \& Khuder, A. (2014). Corporate governance and its role in the reduction of financial and administrative corruption in banks: Study of the views of a sample of employees of private banks in Syria, Tishreen University Journal for Research and Scientific Studies -Economic and Legal Sciences Series, 36(4), 67-88. Retrieved from http://journal.tishreen.edu.sy/index.php/econlaw/article/view/1066

Zanoni, P., \& Janssens, M. (2005). Engaging with (diversity) management: An analysis of minority employees' agency. SSRN Electronic Journal. https://doi.org/10.2139/ssrn.870227 


\section{Appendices}

Appendix A. Characteristics of the Sample

Table 1. The distributed and retrieved questionnaire forms

\begin{tabular}{ccccc}
\hline No. & Group & $\begin{array}{c}\text { The number of the distributed } \\
\text { questionnaire forms }\end{array}$ & $\begin{array}{c}\text { The number of the retrieved } \\
\text { questionnaire forms }\end{array}$ & $\begin{array}{c}\text { Response } \\
\text { Rate }\end{array}$ \\
\hline 1 & $\begin{array}{c}\text { The tax auditors } \\
\text { group }\end{array}$ & 38 & 32 & $84.2 \%$ \\
2 & $\begin{array}{c}\text { The external auditors } \\
\text { group }\end{array}$ & 116 & 61 & $52.5 \%$ \\
\hline Table 2 The respondent's distribution according to their positions
\end{tabular}

Table 2. The respondent's distribution according to their positions

\begin{tabular}{|c|c|c|c|c|c|c|c|c|c|c|}
\hline Position & \multicolumn{2}{|c|}{ Tax auditors } & \multicolumn{2}{|c|}{ Tax supervisors } & \multicolumn{2}{|c|}{$\begin{array}{l}\text { Heads of the auditing } \\
\text { departments }\end{array}$} & \multicolumn{2}{|c|}{ Certified auditors } & \multicolumn{2}{|l|}{ Total } \\
\hline Group & $\mathrm{F}$ & $\mathrm{P} \%$ & $\mathrm{~F}$ & $\mathrm{P} \%$ & $\mathrm{~F}$ & $\mathrm{P} \%$ & $\mathrm{~F}$ & $\mathrm{P} \%$ & $\mathrm{~F}$ & $\mathrm{P} \%$ \\
\hline $\begin{array}{l}\text { The tax } \\
\text { auditors } \\
\text { group }\end{array}$ & 22 & 68.75 & 8 & 25 & 2 & 6.25 & - & - & 32 & 100 \\
\hline $\begin{array}{l}\text { The external } \\
\text { auditors } \\
\text { group }\end{array}$ & - & - & - & - & - & - & 61 & 100 & 61 & 100 \\
\hline
\end{tabular}

*F refers to frequency and P refers to percentage $\%$

Table 3. The respondent's distribution according to their academic qualifications

\begin{tabular}{|c|c|c|c|c|c|c|c|c|}
\hline $\begin{array}{l}\text { Academic } \\
\text { qualification }\end{array}$ & BA & & & & $\mathrm{PhD}$ & & Total & \\
\hline Group & $\mathrm{F}$ & $\mathrm{P} \%$ & $\mathrm{~F}$ & $\mathrm{P} \%$ & $\bar{F}$ & $\mathrm{P} \%$ & $\mathrm{~F}$ & $\mathrm{P} \%$ \\
\hline $\begin{array}{l}\text { The tax auditors } \\
\text { group }\end{array}$ & 25 & 78.125 & 6 & 18.75 & 1 & 3.125 & 32 & 100 \\
\hline $\begin{array}{l}\text { The external } \\
\text { auditors group }\end{array}$ & 54 & 88.52 & 5 & 8.2 & 2 & 3.28 & 61 & 100 \\
\hline
\end{tabular}

*F refers to frequency and P refers to percentage \%

Table 4. The respondent's distribution according to their years of experience

\begin{tabular}{|c|c|c|c|c|c|c|c|c|c|c|c|c|}
\hline \multirow{2}{*}{$\begin{array}{c}\begin{array}{l}\text { Years } \\
\text { experience }\end{array} \\
\text { Group }\end{array}$} & \multirow{2}{*}{$\begin{array}{l}\begin{array}{l}\text { Less } \\
\text { years }\end{array} \\
\mathrm{F}\end{array}$} & \multirow{2}{*}{$\begin{array}{r}\text { than } 5 \\
\mathrm{P} \%\end{array}$} & \multicolumn{2}{|c|}{$6-10$ years } & \multicolumn{2}{|c|}{$10-15$ years } & \multicolumn{2}{|c|}{$16-20$ years } & \multirow{2}{*}{$\begin{array}{c}\begin{array}{c}\text { More } \\
\text { years }\end{array} \\
\mathrm{F}\end{array}$} & \multirow{2}{*}{$\begin{array}{c}\text { than } 20 \\
\text { P \% }\end{array}$} & \multicolumn{2}{|l|}{ Total } \\
\hline & & & $\mathrm{F}$ & $\mathrm{P} \%$ & $\mathrm{~F}$ & P \% & $\mathrm{F}$ & P \% & & & $\mathrm{F}$ & $\mathrm{P} \%$ \\
\hline $\begin{array}{l}\text { The tax } \\
\text { auditors group }\end{array}$ & 6 & 18.75 & 12 & 37.5 & 6 & 18.75 & 5 & 15.625 & 3 & 9.375 & 32 & 100 \\
\hline $\begin{array}{l}\text { The external } \\
\text { auditors group }\end{array}$ & - & - & 11 & 18 & 12 & 19.7 & 17 & 27.9 & 21 & 34.4 & 61 & 100 \\
\hline
\end{tabular}

*F refers to frequency and $\mathrm{P}$ refers to percentage $\%$ 
Appendix B: Attitudes of the respondents towards the statements of the questionnaire in the form of percentages and frequencies

Table 5. Attitudes of the respondents towards the statements related to the study's first question

\begin{tabular}{|c|c|c|c|c|c|}
\hline No. & Statement & $\begin{array}{l}\text { Frequency } \\
\text { (Yes) }\end{array}$ & Percentage \% & $\begin{array}{l}\text { Frequency } \\
\text { (No) }\end{array}$ & Percentage $\%$ \\
\hline 1 & $\begin{array}{l}\text { There must be efforts exerted to involve auditors in } \\
\text { enacting tax related laws and developing tax related } \\
\text { legislations. That shall reduce the levels of financial } \\
\text { and administrative governmental corruption at the } \\
\text { income and sales tax department }\end{array}$ & 87 & 93.5 & 6 & 6.5 \\
\hline 2 & $\begin{array}{l}\text { Incentives must be given to the employees working } \\
\text { at the income and sales tax department. That shall } \\
\text { motivate them and reduce the levels of financial and } \\
\text { administrative governmental corruption at the income } \\
\text { and sales tax department }\end{array}$ & 78 & 83.9 & 15 & 16.1 \\
\hline 3 & $\begin{array}{l}\text { The insufficiency of the tax auditors shall have a } \\
\text { direct impact on the rates of abusing power at the } \\
\text { income and sales tax department }\end{array}$ & 60 & 64.5 & 33 & 35.5 \\
\hline 4 & $\begin{array}{l}\text { Having clear tax legislations shall reduce the rates of } \\
\text { committing manipulative acts by taxpayers. Such acts } \\
\text { may include: offering bribes, using connections for } \\
\text { personal gain and etc..... }\end{array}$ & 88 & 94.6 & 5 & 5.4 \\
\hline 5 & $\begin{array}{l}\text { Having a comprehensive and flexible tax system } \\
\text { shall reduce the rates of committing errors and acts of } \\
\text { cheating and fraud at the income and sales tax } \\
\text { department }\end{array}$ & 75 & 80.6 & 18 & 19.4 \\
\hline 6 & $\begin{array}{l}\text { The principle of legal accountability must be } \\
\text { enforced upon taxpayers in case of commitment any } \\
\text { act of tax evasion. That shall reduce the levels of } \\
\text { financial and administrative governmental corruption } \\
\text { at the income and sales tax department }\end{array}$ & 68 & 73.1 & 25 & 26.9 \\
\hline 7 & $\begin{array}{l}\text { Having a general framework that govern the way } \\
\text { procedures are carried out in the tax department shall } \\
\text { encourage employees and the ones who deal with it } \\
\text { to implement the administrative policies that are } \\
\text { applicable in the department }\end{array}$ & 77 & 82.8 & 16 & 17.2 \\
\hline 8 & $\begin{array}{l}\text { Obliging all the employees of the income and sales } \\
\text { tax department to issue a financial disclosure } \\
\text { statement shall reduce the levels of financial } \\
\text { corruption at the latter department }\end{array}$ & 63 & 67.7 & 30 & 32.3 \\
\hline 9 & $\begin{array}{l}\text { Enforcing an efficient control over the sources of the } \\
\text { information provided to the income and sales tax } \\
\text { department shall reduce the rates of committing acts } \\
\text { of forgery in the taxpayers data }\end{array}$ & 80 & 86.0 & 13 & 14.0 \\
\hline 10 & $\begin{array}{l}\text { Having a valid organizational plan for managing the } \\
\text { taxpayers' files shall reduce the operational costs } \\
\text { paid by the income and sales tax department }\end{array}$ & 89 & 95.7 & 4 & 4.3 \\
\hline 11 & $\begin{array}{l}\text { Work tasks must be distributed well to reduce the } \\
\text { levels of administrative negligence }\end{array}$ & 91 & 97.8 & 2 & 2.2 \\
\hline 12 & $\begin{array}{l}\text { Appointing qualified employees in the right position } \\
\text { in the income and sales tax shall reduce the levels of } \\
\text { financial and administrative governmental corruption } \\
\text { at the latter department }\end{array}$ & 88 & 94.6 & 5 & 5.4 \\
\hline 13 & $\begin{array}{l}\text { Assessing the performance level of the auditors } \\
\text { working at the income and sales tax constantly shall } \\
\text { reduce the rates of committing acts of nepotism }\end{array}$ & 79 & 84.9 & 14 & 15.1 \\
\hline 14 & $\begin{array}{l}\text { Setting a code of ethics and professional conduct for } \\
\text { the auditors working at the income and sales tax shall } \\
\text { reduce the rates of committing acts of embezzlement }\end{array}$ & 80 & 86.0 & 13 & 14.0 \\
\hline 15 & $\begin{array}{l}\text { Having adequate data about the rights and duties of } \\
\text { the auditors working at the income and sales tax } \\
\text { department shall reduce the rates of the accepted } \\
\text { bribes }\end{array}$ & 86 & 92.5 & 7 & 7.5 \\
\hline 16 & $\begin{array}{l}\text { Identifying the responsibilities of each administrative } \\
\text { level in the income and sales tax department shall } \\
\text { reduce the rates of the accepted bribes }\end{array}$ & 83 & 89.2 & 10 & 10.8 \\
\hline & Total & & 855 & & 14.5 \\
\hline
\end{tabular}


Table 6. Attitudes of the respondents towards the statements related to the study's second question

\begin{tabular}{|c|c|c|c|c|c|}
\hline No. & Statement & $\begin{array}{c}\text { Frequency } \\
\text { (Yes) }\end{array}$ & Percentage $\%$ & $\begin{array}{l}\text { Frequency } \\
\text { (No) }\end{array}$ & Percentage $\%$ \\
\hline 17 & $\begin{array}{l}\text { Promoting awareness among taxpayers about tax } \\
\text { related matters through all the possible means shall } \\
\text { reduce the financial and administrative } \\
\text { governmental corruption levels at the income and } \\
\text { sales tax department }\end{array}$ & 77 & 82.8 & 16 & 17.2 \\
\hline 18 & $\begin{array}{l}\text { Holding courses that aim at raising taxpayers' } \\
\text { awareness about their rights and duties shall reduce } \\
\text { the rates of accepted bribes at the income and sales } \\
\text { tax department }\end{array}$ & 85 & 91.4 & 8 & 8.6 \\
\hline 19 & $\begin{array}{l}\text { Taxpayers should notify officers at the income and } \\
\text { sales tax department about the time in which they } \\
\text { should start performing their tasks. That shall } \\
\text { reduce the financial and administrative } \\
\text { governmental corruption levels at the income and } \\
\text { sales tax department }\end{array}$ & 50 & 53.8 & 43 & 46.2 \\
\hline 20 & $\begin{array}{l}\text { Submitting the required tax declarations to the } \\
\text { income and sales tax department on the due time } \\
\text { shall reduce the financial and administrative } \\
\text { governmental corruption levels at the latter } \\
\text { department }\end{array}$ & 87 & 93.5 & 6 & 6.5 \\
\hline 21 & $\begin{array}{l}\text { Providing the income and sales tax department with } \\
\text { valid documents, and records shall reduce the } \\
\text { financial and administrative governmental } \\
\text { corruption levels at the latter department }\end{array}$ & 88 & 94.6 & 5 & 5.4 \\
\hline 22 & $\begin{array}{l}\text { Paying the payable taxes by the taxpayers on the } \\
\text { due time shall reduce the financial and } \\
\text { administrative governmental corruption levels at the } \\
\text { income and sales tax department }\end{array}$ & 67 & 72.0 & 26 & 28.0 \\
\hline 23 & $\begin{array}{l}\text { Preparing the financial statements in accordance } \\
\text { with the international accounting standards shall } \\
\text { reduce the financial and administrative } \\
\text { governmental corruption levels at the income and } \\
\text { sales tax department }\end{array}$ & 88 & 94.6 & 5 & 5.4 \\
\hline 24 & $\begin{array}{l}\text { Editing the facility's records by external auditors } \\
\text { shall reduce the financial and administrative } \\
\text { governmental corruption levels }\end{array}$ & 90 & 96.8 & 3 & 3.2 \\
\hline 25 & $\begin{array}{l}\text { Keeping the taxpayers' financial and accounting } \\
\text { records that are issued regularly shall reduce the } \\
\text { financial and administrative governmental } \\
\text { corruption levels at the income and sales tax } \\
\text { department }\end{array}$ & 75 & 80.6 & 18 & 19.4 \\
\hline 26 & $\begin{array}{l}\text { Having a valid accounting and tax systems } \\
\text { approved by the income and sales tax department } \\
\text { shall reduce the financial and administrative } \\
\text { governmental corruption levels at the latter } \\
\text { department }\end{array}$ & 40 & 43.0 & 53 & 57.0 \\
\hline 27 & $\begin{array}{l}\text { Promoting awareness among the taxpayers about } \\
\text { the income and sales tax act shall make them } \\
\text { comply with it and stop seeking connections for } \\
\text { achieving personal gains } \\
\text { Total }\end{array}$ & 81 & 87.1 & 12 & 12.9 \\
\hline
\end{tabular}

\section{Copyrights}

Copyright for this article is retained by the author(s), with first publication rights granted to the journal.

This is an open-access article distributed under the terms and conditions of the Creative Commons Attribution license (http://creativecommons.org/licenses/by/4.0/). 